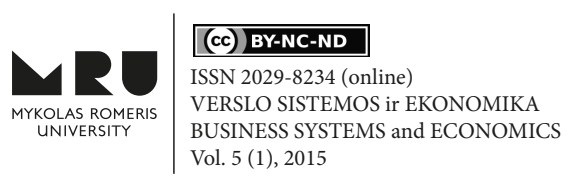

\title{
A LITERATURE REVIEW ON MODELS OF INVENTORY MANAGEMENT UNDER UNCERTAINTY
}

\author{
Serhii ZIUKOV \\ Yurii Fedkovych Chernivtsi National University \\ 2 Kotsjubynskyi str., Chernivtsi 58012, Ukraine \\ E-mail: s.zyukov@chnu.edu.ua
}

doi:10.13165/VSE-15-5-1-03

\begin{abstract}
Inventories are raw materials, work-in-process goods and completely finished goods that are considered to be the portion of business's assets that are ready or will be ready for sale. Formulating a suitable inventory model is one of the major concerns for an industry. The earliest scientific inventory management researches date back to the second decade of the past century, but the interest in this scientific area is still great. Again considering the reliability of any process is an important feature in the research activities. Values of some factors are very hard to define or almost unreal. In such cases, fuzzy models of inventory management take an important place. This paper analyzes possible parameters of existing models of inventory control. An attempt is made to provide an up-to-date review of existing literature, concentrating on descriptions of the characteristics and types of inventory control models that have been developed.
\end{abstract}

Keywords: fuzzy sets, inventory management, models under uncertainty, EOQ, EPQ.

JEL Classification: D890, G31, O21.

\section{Introduction}

The problem of inventory control is one of the most important in organizational management. As a rule, there is no standard solution - the conditions at each company or firm are unique and include many different features and limitations. An occurring task of the mathematical models development and determining the optimal inventory control strategy is related with this problem. Features of inventory management models are that the resulting optimal solutions can be implemented in a fast changing situation where, for example, the conditions are changed daily. There is a need for new and effective methods for modelling systems associated with inventory management, in the face of uncertainty. Uncertainty exists regarding the control object, as the process of obtaining the necessary information about the object is not always possible. The solution of such complex tasks requires the use of systems analysis, development of a systematic approach to the problem of management in general. Inventory models are distinguished by the assumptions made about the key variables: demand, the cost structure, physical characteristics of the system. These assumptions may not suit to the real environment. There is a great deal of uncertainty and variability. 
The research object is models of inventory control under uncertainty. The aim of this paper is to get a broad review of more than 30 research papers and classify the models into groups, identify future research directions.

\section{Inventory management}

Stocks (reserves) are created to carry out the normal activities of the company. Proper and timely determination of the optimal inventory control strategy allows freeing a significant amount of assets, frozen in the form of stocks, which ultimately increases the efficiency of resource use. Even though there are literally millions of different types of products manufactured in our society, there are only two fundamental decisions that one has to make when controlling inventory:

1. How large should an inventory replenishment order be?

2. When should an inventory replenishment order be placed?

The objectives of inventory management often reduce the problem if it is more profitable to do quickly but more expensive or slower but cheaper. Such a strategy will be optimal inventory control, which minimizes the sum of milestones costs associated with the production, storage and inventory shortage per unit of time or for a specific (including infinite) amount of time.

Management models differ in the nature of the available information on the properties of the simulated system. When the value of the model parameters is well-defined, nature of the corresponding mathematical model is deterministic. If the parameters of the system are random values with a known probability, distribution models are stochastic (probabilistic). If all of the model parameters do not change over time, it is called static, otherwise - dynamic. Static models are used when receiving a one-time decision about the level of reserves for a certain period, and dynamic - in the case of sequential decision-making about stock levels or to adjust earlier decisions, taking into account the changes taking place. When static patterns of change in system parameters cannot be installed, it is necessary to solve the problem of inventory management in the face of uncertainty.

In models of inventory management, the following characteristics are taken into account:

Single versus multiple items. This dimension considers whether a single item can be used in isolation for calculations, or whether multiple interdependent products should be taken into account, as a result of collective budget or space constraints, coordinated control or substitutability between items.

Time duration. In some inventory management situations, the selling season for products is short, and excess stock at the end of the season cannot be used to satisfy the demand of the next season. In such cases, a single period model is required. When multiple periods need to be considered, a common approach is to use a rolling horizon implementation approach. Here, decisions consider only a relatively small number of future periods and are made at the start of each period. The decisions are then implemented in the current period, and the problem resolved at the start of the subsequent period.

Number of stocking points. Sometimes, it is appropriate to treat a single stocking point in isolation. In many real world cases, inventories of the same item are kept at more than one location. In multi-echelon situations, the orders generated by one location (e.g., a branch warehouse) become part or all of the demand at another location (e.g., a central warehouse). 
In addition, one can have horizontal multiplicity, that is, several locations at the same echelon level (e.g., several branch warehouses) with the possibility of transhipments and redistributions.

The nature of product. The product type dimension identifies and considers certain product characteristics. For instance, a product may be perishable, consumable, repairable or recoverable. Deterioration of an item in the storage period is a natural process. Therefore, it cannot be ignored in inventory policy. It may be different in different storage places due to the difference in the environment.

Nature of demand. There are a number of possible choices in modelling the demand process.

Types of demand could be classified as it is shown in Figure 1. Deterministic demand is exactly known, unlike the probabilistic demand. It can be of two types. One of them is static, which does not have any variation. The amount of demand known or can be computed with certainty. Second type is dynamic, which may vary. This type of demand varies with time, but the way in which the demand varies is known with certainty.

Figure 1: Types of demand classification

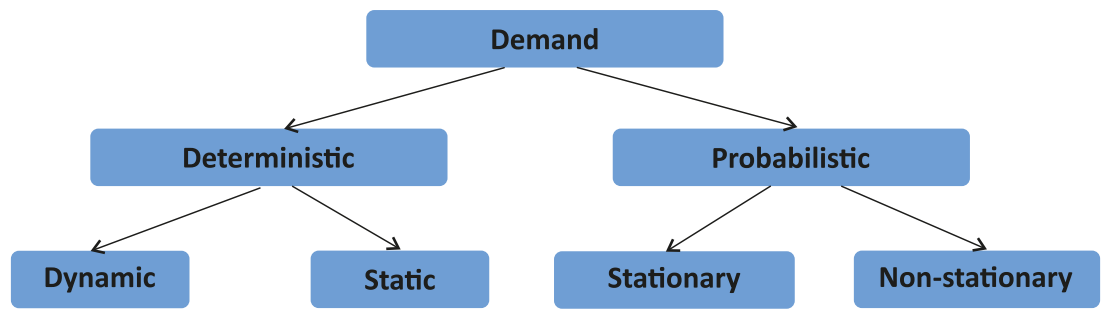

Source: Silver (2008)

Stationary distribution with known parameters. This type of demands follows a probability distribution that is known or estimated from historical data. Commonly used distributions include normal, gamma, Poisson.

Non-stationary probabilistic demand. This type of demand behaves like a random walk that evolves over time, with regular changes in its direction and rate of growth or decline.

On the basis of the demand sources, demands are divided into independent and dependent. Independent demand is the demand that consists of the individual consumers demands, each of them feeling the need independently of the other. Dependent demand occurs when a manufacturer uses a number of components for the manufacture of finished goods, and the demand for each component is associated with other and depends on the production plan of manufacturing.

Nature of supply process. The nature of the supply process refers to any restrictions or constraints that have been imposed on the inbound processes of the supply chain. Minimum or maximum order size or replenishment lead times are examples of typical factors considered in this dimension. Silver (2008) identifies three possible forms of lead-time. The first form is where the lead-time of each replenishment is known; the second is where replenishments arrive after a random time; and the final form is where seasonal factors may affect the 
time it takes for an order to be fulfilled. A supplier usually has limited capacity; therefore, order size restrictions are taken into account in this dissertation. In addition, lead-time is assumed to be a constant and known value.

Penalty and deficit. Any warehouse is established in order to prevent a shortage of a certain type of products handled by the system. Lack of stock at the right time leads to losses associated with downtime, unevenness of production, etc. These losses will be called a penalty for the deficit.

Any model is an abstraction of reality. The more number of dimensions to be taken into account in the model, the greater the model will meet the requirements of the real environment.

It is a challenging task to obtain realistic input values for the mathematical inventory model parameters. The decision-making person performing this task is often operating in an environment, with unknown parameters. In inventory control, it is associated with the uncertainty of customer demand rates, manufacturing and delivery lead times. The models and methods of decision-making in existing theory of inventory management are usually focused on deterministic parameters and modules do not meet the full requirements of the real environment. In such cases, fuzzy models of inventory management take an important place. Fuzzy set theory suggests methods of dealing with imprecision and uncertainty in a quantitate way. Fuzzy logic is widely used in solving problems of riskology, problems of artificial intelligence as in building expert systems, and in combination with artificial neural networks. The theoretical basis of fuzzy logic constitutes the fuzzy sets, proposed by Zadeh (1965). It has gained widespread prominence as a means to model vague data in production management applications. Galbraith (1973) defines uncertainty as the difference between the amount of information required to perform a task and the amount of information already possessed. In the real world, many forms of uncertainty affect production processes. Ho (1989) categorizes them into two groups: environmental uncertainty and system uncertainty. Environmental uncertainty includes uncertainties beyond the production process, such as demand uncertainty and supply uncertainty. System uncertainty is related to uncertainties in the production process, such as operation yield uncertainty, production leadtime uncertainty, and quality uncertainty, failure of the production system and changes to product structure, to mention some. A new stage in the theory of inventory management is the emergence of models taking into account uncertainty. The classification of these models deserves a review (Table 1).

Table 1: Fuzzy models of inventory control classification

\begin{tabular}{|l|l|}
\hline \multicolumn{1}{|c|}{ By purpose } & \multicolumn{1}{c|}{ By period } \\
\hline $\begin{array}{l}\text { - Economic order quantity models } \\
\text { - Economic production quantity models } \\
\text { - Joint economic lot sizing models }\end{array}$ & \begin{tabular}{l} 
- Single-period models \\
\multicolumn{1}{|c|}{ By type of inventory monitoring }
\end{tabular} \\
\hline $\begin{array}{l}\text { - Continuous review system models } \\
\text { - Periodic review system models }\end{array}$ & \multicolumn{1}{c|}{ By quantity of items } \\
\hline
\end{tabular}

Source: Mula (2006) 


\section{Economic order quantity models}

For the fixed order size inventory models, the economic order quantity (EOQ) model is most well-known. The basic EOQ model is a formula for determining the optimal order size that minimizes the sum of carrying costs and ordering costs. The model is derived under a set of restrictive assumptions, as follows:

- Demand is known with certainty and is constant over time.

- No shortages are allowed.

- Lead time of orders is constant.

- The order quantity is received all at once.

The EOQ model was presented originally by Ford W. Harris, in a paper published in 1913 in Factory, The Magazine of Management (Harris, 1913). Many researches were made on the base of this model. However, the coefficients of the model may be fuzzy. One of the first who applied fuzzy theory was K. S. Park, who proposed a single product inventory model with fuzzy parameters on the base of the Harrison model (Park, 1987). Chen and Wang (1996), Roy and Maiti (1997), Yao et al. (2000) and Chang (2004) have extended the well-known EOQ inventory model to fuzzy versions.

Table 2: Economic Order Quantity Model

\begin{tabular}{|l|l|l|l|l|}
\hline \multirow{2}{*}{\multicolumn{1}{|c|}{ Model }} & \multicolumn{4}{c|}{ Model input parameters } \\
\cline { 2 - 5 } & Order Quantity & \multicolumn{1}{|c|}{ Order Cost } & Holding Cost & Annual Demand \\
\hline Park (1987) & Crisp & Fuzzy & Fuzzy & Crisp \\
\hline Lee and Yao (1999) & Fuzzy & Crisp & Crisp & Crisp \\
\hline Yao et al. (2000) & Fuzzy & Crisp & Crisp & Fuzzy \\
\hline Yao and Chiang (2003) & Crisp & Crisp & Fuzzy & Fuzzy \\
\hline Wang et al. (2007) & Crisp & Fuzzy & Fuzzy & Crisp \\
\hline
\end{tabular}

Source: Jaber (2009)

\section{Economic production quantity models}

Economic Production Quantity model (EPQ) determines the quantity a company or retailer should order to minimize the total inventory costs by balancing the inventory holding cost and average fixed ordering cost. The EPQ model was developed by E.W. Taft in 1918 (Taft, 1918). This method is an extension of the EOQ model. The classical economic production quantity model (EPQ) has been widely used. Numerous research efforts have been undertaken to extend the basic EPQ model by releasing various assumptions or adding new so that the model conforms more closely to real-world situations. Recently, re-work activities have attracted considerable attention because of the reduction of the natural resources and the rise in the cost of raw material. Modified Economic Production Quantity models with different schemes of fuzzy input parameters have been proposed by Lee and Yao (1998). The authors fuzzify characteristics, such as demand quantity and the production quantity per day. In the real situation, both of them have little disturbances every day. Chang (1999) considers the production inventory model in which the product quantity is a fuzzy number. Also, based on the numerical example, he compared fuzzy and crisp approaches for solving this problem. Lin and Yao (2000) treat the optimal solution for the fuzzy case of economic 
production for production inventory model. Hsieh (2002) introduced two fuzzy production inventory models with fuzzy parameters for crisp production quantity, or for fuzzy production quantity. The fuzzy total production inventory costs of these models under the fuzzy arithmetical operations of Function Principle were proposed. The authors found optimal solutions of these models by using Graded Mean Integration Representation method for de-fuzzifing fuzzy total production inventory cost and by using Extension of the Lagrangean method for solving inequality constrain problem. Lee and Yao fuzzified the demand quantity and production quantity per day in their model (Lee, 1998).

\section{Joint economic lot sizing models}

Inventory models that address issues of inventory coordination between a buyer and a seller have been extensively studied in the literature. This class of inventory models is commonly referred to as joint economic lot sizing (JELS) models. The objective of these models is the development of a jointly coordinated buyer-seller inventory strategy that is more beneficial to each member's individual non-coordinated inventory strategy. One of the first attempts was made by Lam and Wong (1996), extending the existing model of Dolan. They applied fuzzy mathematical programming to solve the joint economic lot size problem with multiple price breaks. Single and multiple incremental price discounts are modelled as fuzzy numbers.

Das, Roy and Maiti proposed a buyer-seller fuzzy inventory model for a deteriorating item, where deterioration is subject to discount (Das, 2004). In this paper, multi-objective joint economic lot size models are developed in both crisp and fuzzy environments. Here, the objectives are to minimize the buyer's total average cost and to maximize the seller's average revenue. A fuzzy goal programming methodology is used to solve the model.

Ouyang et al. (2006) introduced defective items into the JELS model. The study applies various modelling methods to manage the defective rate in an integrated vendor-buyer inventory model. Three cases are investigated: crisp defective rate, triangular fuzzy defective rate and statistic fuzzy defective rate. In these two fuzzy cases, the signed distance procedure is applied to estimate the joint total expected cost in a fuzzy sense. Yang presented a stylized model to find the optimal strategy for integrated vendor-buyer inventory model with fuzzy annual demand and fuzzy adjustable production rate (Yang, 2007). For the model, Signed distance's ranking method for fuzzy number is employed to find the estimation of the joint total expected annual cost in the fuzzy sense and the corresponding order quantity of the buyer derived accordingly.

\section{Single-period models}

The newsvendor model is a single-period, probabilistic inventory model, which objective is to determine the order quantity that minimizes expected underage costs (costs due to shortage) and overage costs (costs due to holding inventory). First single-period inventory models were designed by D. Petrovic (1996), who has formulated a conception of second level fuzzy set, methods of s-fuzzification and arithmetic defuzzification. Ishii and Konno (1998) introduced fuzziness of shortage cost explicitly into the classical newsboy problem. They investigated the so-called fuzzy newsboy problem where its shortage cost is vague and 
given by an L shape fuzzy number. Then, the total expected profit function was considered to be a fuzzy number. An optimal ordering quantity realizing the fuzzy max order of the profit function (fuzzy min order considering the profit function) was found and compared with the optimal ordering quantity of the non-fuzzy newsboy problem. Kao and Hsu proposed a single-period inventory model with fuzzy demand (Kao and Hsu, 2002). This paper concentrates on possibilistic situations, in which the demands are described by subjectively determined membership functions. For each order quantity Q, a fuzzy total cost composed of the procurement cost, shortage cost and holding cost is associated with it. Dutta et al. present a single-period inventory problem in an imprecise and uncertain mixed environment (Dutta, et al., 2005). The aim of the paper is to introduce demand as a fuzzy random variable. To determine the optimal order quantity, a new methodology was developed for this model in the presence of fuzzy random variable demand where the optimum is achieved using a graded mean integration representation. To illustrate the model, the classical newsboy problem was considered.

\section{Multi-period models}

The main difference between the single-period model and the multi-period model is that the multi-period model may involve stock leftovers from previous periods, which makes the optimal choice of order quantities more complicated.

In real-world applications, inventory and production decisions are interdependent and temporal in nature. Fuzzy logic has been useful in formulating multi-period lot sizing models. The review of multi-period models is described in Table 3.

Table 3: Fuzzy Multi-Period Inventory Models

\begin{tabular}{|l|l|}
\hline \multicolumn{1}{|c|}{ Model } & \multicolumn{1}{c|}{ Key Model Attributes } \\
\hline Sommer (1981) & $\begin{array}{l}\text { Uses fuzzy dynamic programming to determine optimal inventory and produc- } \\
\text { tion levels in a real-world integrated multi-period inventory and production } \\
\text { scheduling problem for an organization engaged in a planned withdrawal from } \\
\text { a market. }\end{array}$ \\
\hline $\begin{array}{l}\text { Kacprzyk and } \\
\text { Staniewski (1982) }\end{array}$ & $\begin{array}{l}\text { Applies fuzzy set theory to determine an optimal aggregate inventory replenish- } \\
\text { ment strategy subject to a set of long-term management objectives. }\end{array}$ \\
\hline Lee et al. (1990) & $\begin{array}{l}\text { Introduces fuzzy logic into material requirements planning (MRP) by defining } \\
\text { period demand as a fuzzy number. A fuzzy part period balancing algorithm is } \\
\text { developed. }\end{array}$ \\
\hline Lee et al. (1991) & $\begin{array}{l}\text { Extends their previous research on multi-period fuzzy lot sizing and introduces } \\
\text { fuzzy versions of the Wagner-Whitin and Silver-Meal lot sizing models. }\end{array}$ \\
\hline Liu (1999) & $\begin{array}{l}\text { Applies fuzzy decision making to investigate optimal inventory policy for a } \\
\text { multi-period inventory system with partial back orders. }\end{array}$ \\
\hline
\end{tabular}

Source: Jaber (2009)

\section{Conclusion}

In the past years, the efficiency of inventory management has become an area of major concern in business. New inventory models for managing the inventory levels are now available. This paper has presented a literature survey of models of inventory control under 
uncertainty. Most of the analytical models addressed only one type of uncertainty and assumed a simple structure of the production process. The most common dimensions to be considered as fuzzy variables are demand, the cost of acquisition.

Each model, based on some assumptions, has its benefits and disadvantages, but still, many authors continue to design inventory control models using such approach as fuzzy logic.

The existence of such quantity of models shows that fuzzy set theory is one of the appropriate methods, which can suppose a great advance in inventory management. The emphasis in each review was to identify how the fuzzy set theory was used in the formulation of the inventory model. The classification and review of models are quite general and can be extended.

\section{Acknowledgements}

This project has been funded with support from the European Commission (No. 204521-1-2011-1-LT-ERA MUNDUS-EMA21). This publication reflects the views only of the author, and the Commission cannot be held responsible for any use which may be made of the information contained therein.

\section{References}

Chang, H.C. (2004). An Application of Fuzzy Sets Theory to the EOQ Model with Imperfect Quality Items. Comput. Oper. Res., 31(12): 2079-2092.

Chang, S.C. (1999). Fuzzy Production Inventory for Fuzzy Product Quantity with Triangular Fuzzy Number. Fuzzy Sets and Systems, 107(1): 37-57.

Chen, S.H., and Wang, C.C. (1996). Backorder Fuzzy Inventory Model under Functional Principle. Inf. Sci., 95: 71-79.

Das, K., Roy, T.K., and Maiti, M. (2004). Buyer-Seller Fuzzy Inventory Model for a Deteriorating Item with Discount. Int J Syst Sci, 35(8): 457-466.

Dutta, P., Chakraborty, D., and Roy, A.R. (2005). A Single-Period Inventory Model with Fuzzy Random Variable Demand. Math Comput Model, 41(8/9): 915-922.

Eilon, S. (1956). Economic Lot Sizes in Batch Production. Engineering, 182(4729): 522-523.

Galbraih, J. (1973). Designing Complex Organizations. Reading, MA: Addison-Wesley.

Harris, F.W. (1913). How Many Parts to Make at Once, Factory. The Magazine of Management, 10(2): $135-136,152$.

Ho, C. (1989). Evaluating the Impact of Operating Environments on MRP System Nervousness. International Journal of Production Research, 27: 1115-1135.

Hsieh, C.H. (2002). Optimization of Fuzzy Production Inventory Models. Information Sciences, 146(1/4): 29-40.

Ishii, H., and Konno, T. (1998). A Stochastic Inventory Problem with Fuzzy Shortage Cost. European Journal of Operational Research, 106(1): 90-94.

Jaber, M.Y. (2009). Inventory Management: Non-classical View. Boca Raton: CRC Press, p. 228.

Kacprzyk, J., and Staniewski, P. (1982). Long Term Inventory Policy-Making through Fuzzy Decision Making. Fuzzy Set Syst, 8: 117-132.

Kao, C., and Hsu, W.K. (2002). A Single-Period Inventory Model with Fuzzy Demand. Computer and Mathematic with Application, 43: 841-848.

Lam, S.M., and Wong, D.S. (1996). A Fuzzy Mathematical Model for Joint Economic Lot Size Problem with Multiple Price Breaks. European Journal of Operational Research, 95(3): 611-622.

Lee, H.M., and Yao, J.S. (1998). Economic Production Quantity for Fuzzy Demand and Fuzzy Production Quantity. European Journal of Operational Research, 109: 203-211. 
Lee, H.M., and Yao, J.S. (1999). Economic Order Quantity in Fuzz Sense for Inventory without Backorder Model. Fuzzy Sets and Systems, 105: 13-31.

Lee, Y.Y., Kramer, B.A., and Hwang, C.L. (1990). Part-Period Balancing with Uncertainty: A Fuzzy Sets Theory Approach. International Journal of Production Research, 28(10): 1771-1778.

Lee, Y.Y., Kramer, B.A., and Hwang, C.L. (1991). A Comparative Study of Three Lot-Sizing Methods for the Case of Fuzzy Demand. Int J Oper Prod Manag, 11(7): 72-80.

Lin, D.C., and Yao, J.S. (2000). Fuzzy Economic Production for Production Inventory. Fuzzy Sets and Systems, 111(3): 465-495.

Liu, B. (1999). Fuzzy Criterion Models for Inventory Systems with Partial Backorders. Ann Oper Res, 87: $117-126$.

Mula, J., Poler, R., Garcia-Sabater, J.P., and Lario, F.C. (2006). Models for Production Planning under Uncertainty: A Review. Int. J. Production Economics, 103(1): 271-285.

Ouyang, L.Y., Wu, K.S., and Ho, C.H. (2006). Analysis of Optimal Vendor-Buyer Integrated Inventory Policy Involving Defective Items. Int J Adv Manuf Tech, 29(11/12): 1232-1245.

Park, K.S. (1987). Fuzzy-Set Theoretic Interpretation of Economic Order Quantity. IEEE Trans. System, Man, Cybernetics, SMC-17: 1082-1084.

Petrovic, D., Petrovic, R., and Vujosevic, M. (1996). Fuzzy Models for the Newsboy Problem. International Journal of Production Economics, 45(1/3): 435-441.

Roy, T.K., and Maiti, M. (1997). A Fuzzy EOQ Model with Demand Dependent Unit Cost under Limited Storage Capacity. European Journal of Operational Research, 99: 425-432.

Silver, E.A. (2008). Inventory Management: An Overview, Canadian Publications, Practical Applications and Suggestions for Future Research. INFOR, 46(1): 15-28.

Sommer, G. (1981). Fuzzy Inventory Scheduling. In G. Lasker (ed.), Applied Systems and Cybernetics, Vol. VI (3052-3060). New York: Pergamon Press.

Taft, E.W. (1918). The Most Economical Production Lot. Iron Age, 101: 1410-1412.

Wagner, H.M. (1980). Research Portfolio for Inventory Management and Production Planning Systems. Operation Research, 28(3): 445-475.

Wang, X., Tang, W., and Zhao, R. (2007). Fuzzy Economic Order Quantity Inventory Models without Backordering. Tsinghua Sci Tech, 12(1): 91-96.

Yang, M.F. (2007). Optimal Strategy for the Integrated Buyer-Vendor Model Fuzzy Annual Demand and Fuzzy Adjustable Production Rate. Journal of Applied Science, 7(7): 1025-1029.

Yao, J.S., Chang, S.C., and Su, J.S. (2000). Fuzzy Inventory without Backorder for Fuzzy Order Quantity and Fuzzy Total Demand Quantity. Comput. Oper. Res., 27: 935-962.

Yao, J.S., and Chiang, J. (2003). Inventory without Backorder with Fuzzy Total Cost and Fuzzy Storing Cost De-fuzzified by Centroid and Signed Distance. European Journal of Operational Research, 148(2): 401-409.

Zadeh, L.A. (1965). Fuzzy Sets. Information and Control, 8: 338-353.

\title{
LITERATŪROS APIE ATSARGUৃ VALDYMO MODELIŲ NEAPIBRĖŽTUMĄ APŽVALGA
}

\author{
Serhii ZIUKOV \\ Jurijaus Fedkovičiaus Černivcių nacionalinis universitetas, Ukraina
}

Santrauka. Atsargos - žaliavos, nebaigtos gamybos prekès ir visiškai gatavos prekès, kurios yra laikomos verslo turto dalimi, kuri jau yra ar bus parengta parduoti. Tinkamo atsargų modelio formavimas yra vienas iš pagrindinių pramonès interesų. Atsargų valdymo moksliniai tyrimai pradèti praejusio šimtmečio antrą dešimtmetị, tačiau interesas šioje mokslinejje srityje yra vis dar didelis. Atsižvelgti ị bet kokių procesų patikimumą yra svarbi mokslinių tyrimų ypatybẻ. Kai kurių veiksnių reikšmes labai sunku ar beveik neįmanoma apibrež̌ti. Tokiais atvejais neraiškieji atsargų valdymo modeliai užima svarbią 
vietą. Šiame straipsnyje analizuojami galimi esamų atsargų modelių valdymo parametrai. Bandoma pateikti naujausios esamos literatūros apžvalgą, sutelkiant dėmesị ị atsargų valdymo modelių požymių ir tipų, kurie buvo išplètoti, aprašymus. EPQ.

Reikšminiai žodžiai: neraiškieji rinkiniai, atsargų valdymas, neapibrèžtumo modeliai, EOQ, 